\title{
Analisa Faktor-faktor Penyebab Tidak Lengkapnya Laporan Standar Pelayanan Minimal Rumah Sakit di Rumah Sakit Muhammadiyah Ahmad Dahlan Kota Kediri
}

\section{Analysis on Factors Causing Incompleteness of Hospital Minimum Service Standards Report in Ahmad Dahlan Muhammadiyah Hospital Kediri}

\author{
Edy Supriyanto ${ }^{1}$, Tita Hariyanti' ${ }^{2}$, Erika Widayanti $L^{3}$ \\ ${ }^{1}$ Rumah Sakit Umum Daerah Gambiran Kediri \\ ${ }^{2}$ Program Studi Magister Manajemen Rumah Sakit Fakultas Kedokteran Universitas Brawijaya Malang \\ ${ }^{3}$ Rumah Sakit Muhammadiyah Achmad Dahlan Kediri
}

\begin{abstract}
ABSTRAK
Penelitian ini bertujuan untuk mengetahui faktor-faktor penyebab tidak lengkapnya laporan Standar Pelayanan Minimal (SPM) Rumah Sakit di rumah sakit Muhammadiyah Ahmad Dahlan Kota Kediri. Penelitian ini merupakan penelitian deskriptif kualitatif. Metode pengambilan data berupa wawancara dan observasi di RS Muhammadiyah Ahmad Dahlan Kota Kediri selama bulan Oktober hingga November 2013. Analisis fishbone digunakan untuk identikasi akar masalah dilanjutkan dengan Focus Group Discussion (FGD) untuk memilih akar masalah yang paling penting dan alternatif solusi. Hasil penelitian ini menunjukkan akar masalah yang diidentifikasi pergantian Tim Mutu RS yang tidak berjalan dengan baik dan tidak lengkapnya anggota sehingga menyebabkan tidak berjalannya program peningkatan mutu berkelanjutan dan pencapaian SPM. Pembentukan kembali Tim Mutu dengan tepat, dan kelengkapan organiknya menjadi titik awal solusi implementasi manajemen mutu di rumah sakit.
\end{abstract}

Kata Kunci: Tidak lengkapnya laporan SPM, tim mutu RS

\section{ABSTRACT}

This study aims to determine the factors causing incomplete reports of Minimum Service Standards (MSS) in Ahmad Dahlan Muhammadiyah Hospital Kediri. This research is a qualitative descriptive study. Data collection methods were interviews and observations in Ahmad Dahlan Muhammadiyah Hospital Kedirifrom October to November 2013. Fishbone analysis was used to identify the root of the problem and followed by a Focus Group Discussion to select the most important root of problem and alternative solutions. The results of this study indicate that the root of the problem identified, that were namely the reformation of Quality Team RS is not running well and incomplete members, initiates the ineffectiveness of continuous quality improvement program and the achievement of the MSS. Re-establishment of the proper Quality Team and its organic completeness will be the starting point of quality management solution implementation in the hospital.

Keywords: Incomplete MSS report, hospital's quality control team

Jurnal Kedokteran Brawijaya, Vol. 28, Suplemen No. 1, 2014: Edy Supriyanto. Rumah Sakit Umum Daerah Gambiran Kediri, Jl. KH. Wachid Hasyim 64 Kediri Tel. (0354) 774494 Email:edosurg27@yahoo.co.id 


\section{PENDAHULUAN}

Undang-Undang No. 44 tahun 2009 menyatakan bahwa rumah sakit adalah institusi pelayanan kesehatan yang menyelenggarakan pelayanan kesehatan perorangan secara paripurna yang menyediakan pelayanan rawat inap, rawat jalan, dan gawat darurat (1). Menurut Griffith dalam Trimumpuni (2), rumah sakit terbagi menjadi dua definisi, yaitu definisi struktural dan fungsional. Definisi struktural adalah suatu fasilitas yang memberikan perawatan rawat inap dan pelayanan untuk observasi, diagnosa dan pengobatan aktif untuk individu dengan keadaan medis, bedah, kebidanan, penyakit kronis dan rehabilitasi yang memerlukan pengarahan dan pengawasan seorang dokter setiap hari. Definisi fungsional rumah sakit adalah suatu institusi dengan tujuan untuk menyelenggarakan perawatan kesehatan pribadi dengan memanfaatkan sumber yang dimiliki secara efektif untuk kepentingan masyarakat (2).

Rumah Sakit dalam menjalankan fungsinya sebagai institusi yang memberikan pelayanan kesehatan kepada masyarakat, menggunakan Standar Pelayanan Minimal (SPM) Rumah Sakit yang telah diterapkan oleh Kementerian Kesehatan dengan beberapa kriteria. Pusat data dan informasi dalam manajemen rumah sakit mempunyai peranan penting dalam pengelolaan data rumah sakit untuk memenuhi kriteria-kriteria dalam standar yang telah ditetapkan. Standar tersebut juga dapat berfungsi untuk membantu menilai sejauh mana rumah sakit berhasil mewujudkan visi dan misi rumah sakit. Secara mendasar, terdapat tiga kriteria dengan masing-masing tolok ukurnya yaitu kriteria yang berkaitan dengan penyelenggaraan manajemennya, misalnya efisiensinya; kriteria yang berkaitan dengan jangkauan pelayanan kepada masyarakat antara lain cakupannya; dan kriteria yang dikaitkan dengan mutu pelayanan medis dan perawatan (3).

Rumah sakit wajib menerapkan SPM sesuai dengan Keputusan Menteri Kesehatan Republik Indonesia Nomor: 129/Menkes/SK/II/2008 tentang SPM Rumah Sakit. Berdasarkan Kepmenkes tersebut, Standar Pelayanan Minimal adalah ketentuan tentang jenis dan mutu pelayanan dasar yang merupakan urusan wajib daerah yang berhak diperoleh setiap warga secara minimal. Standar Pelayanan Minimal Rumah Sakit dalam pedoman ini meliputi jenis-jenis pelayanan, indikator dan standar pencapaian kinerja pelayanan rumah sakit.

Jenis-jenis pelayanan rumah sakit yang minimal wajib disediakan oleh rumah sakit meliputi: pelayanan gawat darurat, rawat jalan, rawat inap, bedah, persalinan dan perinatologi serta pelayanan intensif yang seluruhnya merupakan jenis pelayanan medik di rumah sakit. Selain itu terdapat pelayanan penunjang medik yang meliputi pelayanan radiologi, laboratorium patologi klinik, pelayanan rehabilitasi medik, farmasi, gizi, transfusi darah, keluarga miskin, rekam medis, pengelolaan limbah, administrasi manajemen, ambulans dan kereta jenazah, pemulasaraan jenazah, laundry, pemeliharaan sarana rumah sakit, dan pencegah pengendalian infeksi. Masingmasing pelayanan tersebut memiliki indikator dan standar yang wajib dipenuhi oleh rumah sakit (4).

Mutu pelayanan adalah ukuran dari penilaian atas beberapa unit pelayanan. Penilaian mutu erat hubungannya dengan proses penyusunan standar pelayanan yang meliputi empat langkah utama, yaitu menentukan kebutuhan dan lingkup standar, menerapkan standar, evaluasi, dan pembaruan (updating) standar. Terdapat 3 (tiga) pendekatan penilaian standar mutu, yaitu (1) standar struktur yang meliputi aspek fisik, sarana organisasi dan sumber daya manusia; (2) standar proses, yaitu tahapan kegiatan yang dilakukan dalam pelayanan; (3) standar hasil, yaitu outcome dari proses kegiatan pelayanan yang diharapkan (5).

Indikator mutu pelayanan di RS Muhammadiyah Ahmad Dahlan Kota Kediri belum sepenuhnya menerapkan Standar Pelayanan Minimal sesuai dengan Keputusan Menteri Kesehatan Republik Indonesia Nomor: 129/Menkes/SK/II/2008. Berdasarkan data yang ada, tidak semua indikator mutu pelayanan dinilai. Penilaian hanya dilakukan pada 8 pelayanan $(38,1 \%)$ yaitu: layanan rawat jalan, IGD, rawat inap, bedah sentral, farmasi, laboratorium, radiologi dan rekam medis. Hal ini mungkin bisa disebabkan oleh keengganan untuk mengisi atau

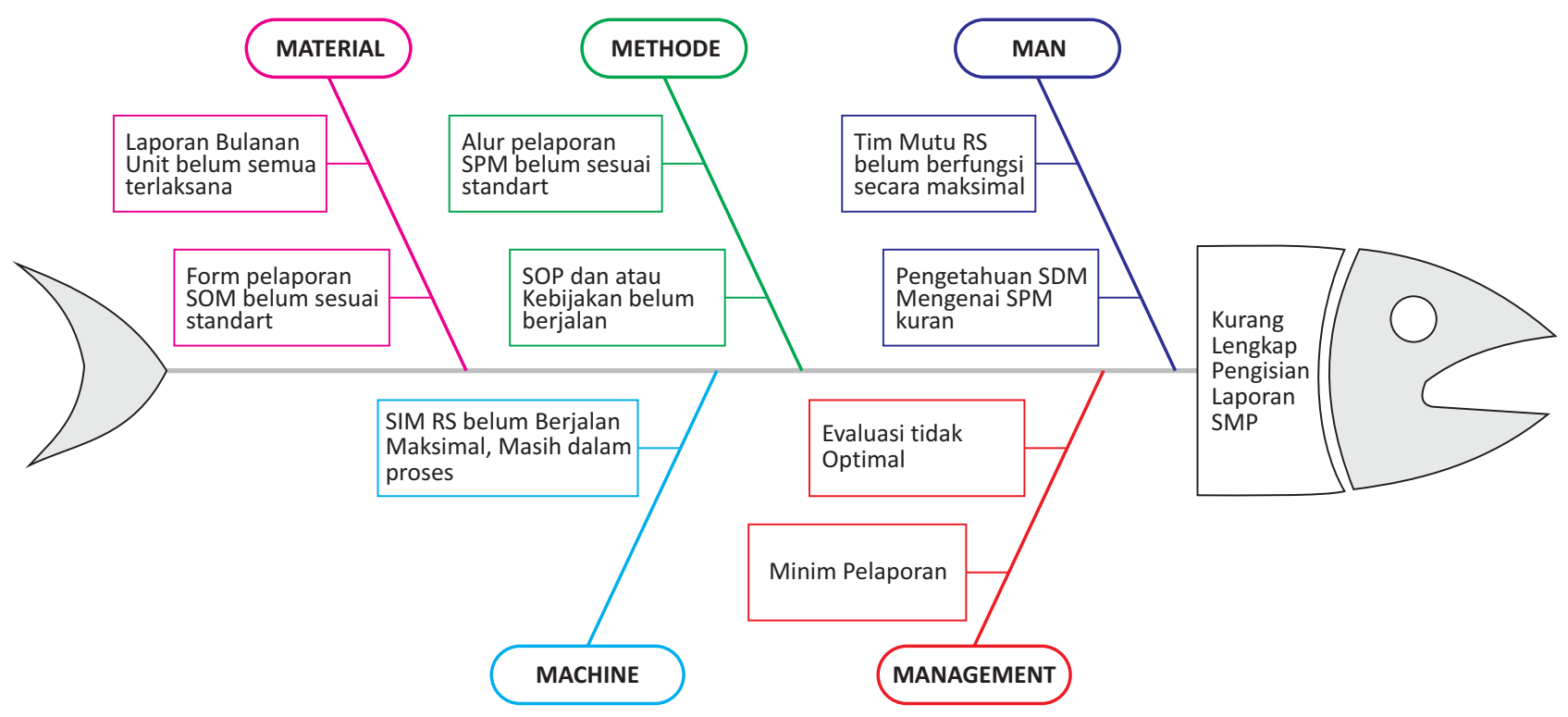

Gambar 1. Diagram fishbone hipotesis faktor-faktor penyebab masalah 
melakukan penilaian, dan belum dijalankan program tersebut. Apabila tidak segera dilakukan perbaikan maka akan berdampak pada tidak berjalannya evaluasi, riset dan perbaikan panduan yang berkelanjutan.

Penelitian ini bertujuan untuk mengetahui faktor-faktor penyebab ketidaklengkapan laporan Standar Pelayanan Minimal RS Muhammadiyah Ahmad Dahlan Kota Kediri. Apabila faktor-faktor penyebab tersebut dapat diketahui, maka diharapkan dapat digunakan sebagai dasar kebijakan perbaikan laporan yang telah ada agar sesuai dengan ketentuan yang berlaku.

\section{METODE}

Studi ini merupakan penelitian deskriptif kualitatif. Metode pengambilan data berupa wawancara dan observasi di RS Muhammadiyah Ahmad Dahlan Kota Kediri selama bulan Oktober hingga November 2013. Wawancara dilakukan mendalam kepada manajemen rumah sakit yaitu kepada Direktur dan Kabid Yangmed pada aspek proses dan kebijakan manajemen. Observasi langsung digunakan untuk memperoleh gambaran faktorfaktor penyebab ketidaklengkapan pengisian Laporan Standar Pelayanan Minimal yang kemudian dianalisis menggunakan diagram fishbone (Gambar 1). Wawancara dilakukan terhadap Direktur dan kepada Kabid Yanmed mengenai aspek-aspek yang berhubungan dengan management, man, methode, material dan machine.

Berdasarkan analisia fishbone tersebut dapat digambarkan faktor-faktor penyebab ketidak lengkapan pengisian laporan SPM. Pada dimensi Man didapatkan tim mutu RS sebenarnya sudah ada tapi ketuanya sudah pindah dan baru diperbarui kepengurusannya sehingga tidak bekerja secara optimal. Pengetahuan SDM mengenai SPM juga masih kurang, karena mereka tidak tahun tentang SPM yang sesuai dengan strandar DEPKES. Mereka membuat laporan SPM/Mutu Pelayanan Rumah Sakit tapi belum memahami berdasarkan apa kritria itu dibuat. Pada dimensi management ditemukan evaluasi terhadap pelaporan SPM selama ini tidak berjalan optimal, karena selama ini laporan SPM tidak pernah disesuaikan dengan standar Kementerian Kesehatan RI. Laporan SPM selama ini tidak lengkap baik dari kriteria maupun dari unit-unit yang ada. Pada dimensi methode didapatkan petugas di unit-unit RS belum memahami laporan SPM, bagaimana harus membuat dan kepada siapa laporan SPM itu dilaporkan. Kebijakan dan SOP dari RS untuk pelaporan SPM yang sesuai standar DEPKES sudah ada tapi tidak berjalan sesuai yang diharapkan. Pada dimemsi material diperoleh bahwa laporan SPM/Mutu Pelayanan Rumah Sakit selama ini dari Unit tidak lengkap dan ada yang belum membuat laporan. Untuk laporan SPM yang sesuai standar Kementerian Kesehatan tidak ada, ini disebabkan form laporan yang belum ada. Pada dimensi machine didapatkan bahwa selama ini laporan Mutu Pelayanan Rumah Sakit dibuat secara manual di masing-masing unit, tidak ada koneksi antara unuit-unit tersebut dengan kantor pelayanan Rumah Sakit.

Untuk mengetahui akar masalah penyebab ketidaklengkapan pengisian laporan SPM tersebut, dilakukan Focus Group Discussion (FGD) sebanyak dua kali. FGD pertama dihadiri oleh peserta sejumlah 21 orang. Peserta yang hadir adalah Kabid Yanmed, dari administrasi dan manajemen 4 Orang (Sekretariat, Personalia, Keuangan dan Kasir), serta dari masing unit rumah sakit. Pada kegiatan ini, berdasakan kesepakatan bersama dipilih akar masalah yang paling penting penyebab ketidak lengkapan laporan SPM rumah sakit. Pada FGD kedua dihadiri oleh peserta sejumlah 19 orang. Peserta yang hadir adalah Direktur, Kabid Yanmed, dari administrasi dan manajemen (Sekretariat, Personalia, Keuangan dan Kasir), serta perwakilan dari masing instalasi/unit rumah sakit, dan ambulan. Pada kegiatan ini dilakukan pemilihan alternatif solusi terbaik yang dapat dilakukan.

\section{HASIL}

Berdasarkan $F G D$ bersama manajemen rumah sakit, diperoleh akar masalah penyebab ketidaklengkapan pengisian laporan SPM adalah akumulasi dari faktor-faktor

\section{Tabel 1. Hasil FGD akar masalah}

\begin{tabular}{|c|c|c|}
\hline No & Identifikasi Masalah & Why (akar masalah) \\
\hline 1. & Tim Mutu RS belum berjalan & $\begin{array}{l}\text { Sumber Daya Manusia yang tidak maksimal : } \\
\text { - } \quad \text { Pergantian Ketua Tim Mutu yang tidak berjalan dengan baik. } \\
\text { - Tim Mutu yang tidak lengkap anggotanya. }\end{array}$ \\
\hline 2. & Laporan bulanan unit belum sesuai dengan SPM & $\begin{array}{l}\text { - Kebijakan SPO pelaporan mutu belum disosialisasikan. } \\
\text { - Belum melaksanakan standar yang sesuai DEPKES. }\end{array}$ \\
\hline 3. & Alur pelaporan SPM belum berjalan & Kebijakan SPO belum ditindaklanjuti. \\
\hline 4. & Form laporan SPM belum tersedia & $\begin{array}{l}\text { Sarana dan prasarana: } \\
\text { - Tidak semua tersedia alat ukur untuk respon time, misalnya: jam } \\
\text { mesin antrian pasien } \\
\text { - Kotak kepuasan pasien belum tersedia. } \\
\text { - Infra struktur yang tersedia belum maksimal. }\end{array}$ \\
\hline 5. & SPO dan atau kebijakan belum berjalan & Belum ada sosialisasi secara terjadwal ke seluruh Unit RS. \\
\hline 6. & Evaluasi tidak optimal & $\begin{array}{l}\text { - Direksi dan Tim sedang dalam proses meningkatkan pengetahuan dan } \\
\text { pemahaman tentang Mutu RS. } \\
\text { SDM yang kurang memadai dan mencukupi baik kuantitas maupun } \\
\text { kualitas. }\end{array}$ \\
\hline $\begin{array}{l}7 . \\
8 .\end{array}$ & $\begin{array}{l}\text { Pengetahuan SDM yang kurang mengenai SPM } \\
\text { SIM RS belum ada }\end{array}$ & $\begin{array}{l}\text { Belum semua mendapat sosialisasi dan pelatihan tentang SPM rumah sakit. } \\
\text { - } \quad \text { Keterbatasan SDM IT } \\
\text { - } \quad \text { Biaya SIM RS yang tinggi sehingga perlu memprioritaskan program. } \\
\text { - Sarana server yang belum sesuai dengan standar }\end{array}$ \\
\hline
\end{tabular}


Tabel 2. Alternatif solusi berdasar akar masalah

\begin{tabular}{|c|c|c|}
\hline No & Why (akar masalah) & Alternatif Solusi \\
\hline 1. & $\begin{array}{l}\text { Sumber Daya Manusia yang tidak maksimal : } \\
\text { - Pergantian Ketua Tim Mutu yang tidak berjalan } \\
\text { dengan baik. } \\
\text { - Tim Mutu yang tidak lengkap anggotanya. }\end{array}$ & Dibentuk Tim Mutu baru beserta uraian tugas masing-masing. \\
\hline 2. & $\begin{array}{l}\text { - Direksi dan Tim sedang dalam proses meningkatkan } \\
\text { pengetahuan dan pemahaman tentang Mutu RS. } \\
\text { SDM yang kurang memadai dan mencukupi baik } \\
\text { kuantitas maupun kualitas. }\end{array}$ & $\begin{array}{l}\text { Meningkatkan pengetahuan tentang Mutu RS melelui seminar } \\
\text { dan workshop. }\end{array}$ \\
\hline 3. & $\begin{array}{l}\text { - Kebijakan SPO pelaporan mutu belum } \\
\text { disosialisasikan. } \\
\text { - } \quad \text { Belum melaksanakan standar yang sesuai DEPKES. }\end{array}$ & $\begin{array}{l}\text { Dibuatkan Surat Keputusan tentang Kebijakan, SPO dan } \\
\text { disosialisasikan melalui rapat struktural di semua unit oleh } \\
\text { Direksi. }\end{array}$ \\
\hline 4. & Kebijakan SPO belum ditindaklanjuti. & Membuat alur pelaporan sesuai standar DEPKES. \\
\hline 5. & $\begin{array}{l}\text { Sarana dan prasarana : } \\
\text { - } \quad \text { Tidak semua tersedia alat ukur untuk respon time, } \\
\text { misalnya: jam mesin antrian pasien. } \\
\text { - } \quad \text { Kotak kepuasan pasien belum tersedia. } \\
\text { - Infra struktur yang tersedia belum maksimal. }\end{array}$ & $\begin{array}{l}\text { - } \quad \text { Membuat form laporan SPM. } \\
\text { sarana prasarana yang mendukung mutu RS. }\end{array}$ \\
\hline 6. & Belum ada sosialisasi secara terjadwal ke seluruh Unit RS. & sosialisasi dan pelatihan tentang mutu dan SPM kepada SDM. \\
\hline 7. & $\begin{array}{l}\text { Belum semua mendapat sosialisasi dan pelatihan tentang } \\
\text { SPM rumah sakit. }\end{array}$ & $\begin{array}{l}\text { Membuat jadwal rutin rapat dan sosialisai tentang Mutu RS ke } \\
\text { Unit-unit RS. }\end{array}$ \\
\hline 8. & $\begin{array}{l}\text { - } \quad \text { Keterbatasan SDM IT. } \\
\text { Biaya SIM RS yang tinggi sehingga perlu } \\
\text { memprioritaskan program. } \\
\text { - Sarana server yang belum sesuai dengan standar. }\end{array}$ & $\begin{array}{l}\text { - Tersedianya SDM Informasi Tehnologi yang penuh waktu. } \\
\text { - } \quad \text { Melengkapi komputer di setiap unit. } \\
\text { - Menyusun RAB yang mendukung SIM RS. }\end{array}$ \\
\hline
\end{tabular}

penyebab yang ada sehingga diputuskan untuk melakukan solusi yang luas mencakup semua faktorfaktor penyebab. Tabel 1 menyajikan berbagai akar masalah penyebab ketidaklengkapan pengisian laporan SPM yang secara garis besar meliputi SDM tim mutu yang tidak maksimal, belum melaksanakan standar sesuai DEPKES, kurangnya sosialisasi, sarana dan prasarana yang belum memadai termasuk di dalamnya sarana SIM RS.

Pada Tabel 2 disajikan alternatif solusi dari berbagai akar masalah yang ditemukan. Solusi yang dipilih untuk dilaksanakan berupa pembentukan tim mutu baru sebagai penanggung jawab terlaksananya pelaporan SPM yang lengkap, pembuatan dan sosialisasi kebijakan atau SOP pendukung agar pengisian laporan SPM lengkap, pembuatan form dan alur pelaporan yang sesuai standar, dan sosialisasi dan pelatihan tentang mutu dan SPM kepada SDM. Pemilihan alternatif solusi ini berdasarkan sarana prasarana dan SDM yang ada serta dapat segera dilaksanakan dalam waktu yang singkat selama penelitian ini.

\section{DISKUSI}

Mutu pelayanan rumah sakit dapat ditelaah dari tiga hal yaitu: struktur (sarana fisik, peralatan, dana, tenaga kesehatan dan non kesehatan, serta pasien); proses (manajemen RS baik manajemen interpersonal, teknis maupun pelayanan keperawatan yang kesemuanya tercermin pada tindakan medis dan non medis kepada pasien); outcome (6). Aspek mutu yang dapat dipakai sebagai indikator untuk menilai mutu pelayanan RS yaitu: penampilan keprofesian (aspek klinis), efisiensi dan efektivitas, keselamatan dan kepuasan pasien (7). Mutu pelayanan RS dapat dilihat dari laporan mutu RS. Laporan Standar Pelayanan Minimal adalah ketentuan tentang jenis dan mutu pelayanan dasar yang merupakan urusan wajib daerah yang berhak diperoleh setiap warga secara minimal (4). Menurut Wijono mutu pelayanan RS dapat diartikan sebagai kepatuhan terhadap standar yang telah ditetapkan (8).

Ketidaklengkapan pengisian laporan Standar pelayanan Minimal (SPM) di RS Muhammadiyah Ahmad Dahlan Kota Kediri disebabkan oleh berbagai faktor. Berdasar wawancara dan observasi yang telah dilakukan menghasilkan beberapa faktor penyebab yang dilihat dari 5 dimensi yaitu man, management, methode, material, dan machine. Dilihat dari dimensi ketenagaan (man), tim mutu RS sebenarnya sudah ada tetapi ketuanya sudah pindah dan baru diperbarui kepengurusannya sehingga tidak bekerja secara optimal. Pengetahuan SDM mengenai SPM juga masih kurang, karena mereka tidak tahu tentang SPM yang sesuai dengan standar Kementerian Kesehatan RI. Mereka membuat laporan SPM/Mutu Pelayanan Rumah Sakit tetapi belum memahami berdasarkan apa kriteria itu dibuat. Menurut Brown et al, salah faktor yang mempengaruhi mutu pelayanan kesehatan adalah kompetensi teknis, yaitu ketrampilan, kemampuan dan penampilan petugas dan tim mutu RS (9). Apabila dilihat dari dimensi management menunjukkan bahwa evaluasi terhadap pelaporan SPM selama ini tidak berjalan optimal, karena selama ini laporan SPM tidak pernah dilakukan perubahan kriteria sesuai dengan standar Kementerian Kesehatan RI. Laporan SPM selama ini tidak lengkap baik dari kriteria maupun dari unit-unit yang ada. Pelaporan kinerja mutu sangat penting dalam proses manajemen mutu. Menurut Zeithaml mutu jasa atau pelayanan RS dipengaruhi oleh cepat tanggap dari evaluasi manajemen terhadap laporan mutu RS (10).

Pada dimensi methode, faktor penyebab yang muncul adalah alur yang belum sesuai standar. Petugas di unit-unit RS belum memahami laporan SPM, bagaimana harus membuat dan kepada siapa laporan SPM itu dilaporkan. Kebijakan dan SOP dari RS untuk pelaporan SPM yang 
sesuai standar Kementerian Kesehatan pun sudah ada tapi tidak berjalan sesuai yang diharapkan. Evaluasi dan perubahan terhadap kebijakan oleh manajemen diperlukan untuk membuat laporan mutu RS yang bisa menggambarkan mutu layanan RS (11). Pada dimensi material, laporan SPM pelayanan rumah sakit selama ini dari unit tidak lengkap dan bahkan ada yang belum membuat laporan. Untuk laporan SPM yang sesuai standar Kementerian Kesehatan tidak ada disebabkan form laporan yang belum ada. Kemudian pada dimensi terakhir yaitu machine, faktor yang muncul adalah bahwa selama ini laporan mutu pelayanan rumah sakit dibuat secara manual di masing-masing unit, sehingga tidak ada koneksi antara unit-unit tersebut dengan kantor pelayanan rumah sakit. Adanya koneksi antara unit-unit

\section{DAFTAR PUSTAKA}

1. Sekretariat Negara Republik Indonesia. Undangundang no 44 tahun 2009 Tentang Rumah Sakit. Jakarta: Sekretariat Negara Republik Indonesia; 2009.

2. Trimumpuni EN. Analisis Pengaruh Persepsi Mutu Pelayanan Asuhan Keperawatan terhadap Kepuasan Klien Rawat Inap RSU Puri Asih Salatiga. [Tesis]. Universitas Diponegoro, Semarang. 2009.

3. Respati T, Djoerban B, dan Maryani H. Penerapan Metode Barber Johnson untuk Menilai Efisiensi Pelayanan Rumah Sakit di Indonesia. Buletin Penelitian Sistem Kesehatan. 2001; 4(1): 41-52.

4. Departemen Kesehatan Republik Indonesia. Standar Pelayanan Minimal Rumah Sakit. Jakarta: Depkes RI; 2008.

5. Najori dan Kuntjoro T. Mutu Pelayanan Keperawatan Anestesi Di Rumah Sakit Umum Daerah Sanggau. dan hubungan yang baik antar petugas mempengaruhi pembuatan laporan mutu RS (12).

Kajian di RS Muhammadiyah Ahmad Dahlan mengidentifikasi akar masalah ketidaklengkapan laporan SPM dengan akar masalah pergantian Tim Mutu RS yang tidak berjalan dengan baik dan tidak lengkapnya anggota. Pembentukan tim yang tidak tepat sangat mempengaruhi kinerja tim, karena ketidaksesuaian kebutuhan kinerja dan kualifikasi anggota. Ketidaklengkapan anggota akan menyebabkan hambatan berjalannya fungsi tim. Perancangan ulang tim, dengan kelengkapan anggota yang tepat dan didukung kebijakan implementasi akan mendorong keterlaksanaan program manajemen mutu dan terdokumentasinya kinerja SPM.

[Tesis]. Universitas Gajah Mada, Yogyakarta. 2010.

6. Donabedian A. The Quality of Care: How Can it be Assessed? The Journal of the American Medical Association. 1988; 260(12): 1743-1748.

7. Jacobalis S. Menjaga Mutu Pelayanan di Rumah Sakit (Quality Assurance). Jakarta: Persi; 1989.

8. Wijono D. Manajemen Mutu Pelayanan Kesehatan. Surabaya: Airlangga University Press; 1999.

9. Brown TJ, Churchill GA Jr, and Peter JP. Improving the Measurement of Service Quality. Journal of Retailing. 1993; 69(1): 127-139.

10. ZeithamI VA, Parasuraman A, and Berry LL. Delivering Quality Service: Balancing Customer Perceptions and Expectations. New York: Simon and Schuster; 1990.

11. Kenagy JW, Berwick DM, and Shore MF. Service Quality in Health Care. The Journal of the American Medical Association. 1999; 281(7): 661-665. 